\title{
Life cycle of a freshwater Gondwanic remnant polychaete Stratiodrilus aeglaphilus (Annelida: Eunicida: Histriobdellidae), commensal with Aegla laevis (Crustacea: Anomura)
}

\section{Ciclo de vida de un poliqueto dulceacuícola de origen Gondwánico Stratiodrilus aeglaphilus (Annelida: Eunicida: Histriobdellidae), comensal de Aegla laevis (Crustacea: Anomura)}

\author{
IRMA VILA ${ }^{1} \&$ DAVID VÉLIZ ${ }^{1,2^{*}}$ \\ ${ }^{1}$ Departamento de Ciencias Ecológicas. \\ ${ }^{2}$ Instituto de Ecología y Biodiversidad, Facultad de Ciencias, Universidad de Chile, Casilla 653, Santiago, Chile. \\ *Email: dveliz@uchile.cl
}

\begin{abstract}
Within the Annelida phylum, the Histriobdellidae Family groups freshwater polychaetes sharing an ancient Gondwanic relationship; very little is known about their life histories. Here we describe the life cycle of Stratiodrilus aeglaphilus, an epibiont of the crab Aegla laevis, which inhabits rivers of central Chile. All its life stages were found associated with $A$. laevis. The presence of a chitinous penis and its larger size permit distinguishing males from females. The observation of larvae/embryos at different development stages allowed us determining the absence of a free-swimming larvae stage in this species; recently hatched juveniles have movements similar to those of adults. S. aeglaphilus shows direct development; different embryo development stages could be observed in the coxal base of the Aegla pereiopods, where all females migrate for oviposition. The life cycle described here is similar to the cycle of other marine organisms such as molluscs and crustaceans. These organisms have adapted to limnic systems by changing their life cycles and showing an absence of planktonic larvae that ensures higher survival in these environments.
\end{abstract}

KEYwords: Annelida; freshwater polychaete; epibiont; Aegla laevis; Chile

\section{RESUMEN}

Dentro del grupo Annelida, la Familia Histriobdellidae agrupa poliquetos dulceacuícolas los cuales tienen una antigua relación Gondwánica, sin embargo existe escaza información acerca de sus historias de vida. En el presente trabajo se describe el ciclo de vida de Stratiodrilus aeglaphilus, un epibionte del crustáceo Aegla laevis, el cual habita ríos de la zona central de Chile. Todos los estados de vida de $S$. aeglaphilus se encontraron asociados al crustáceo A. laevis. La presencia de un pene quitinoso en machos y su mayor tamaño permite diferenciar los sexos. La observación de embriones y larvas en diferentes estados del desarrollo indican que esta especie no posee una larva libre nadadora. Los juveniles recién eclosionados se desplazan de la misma forma que los adultos. Diferentes estados de desarrollo larvario pueden ser observados en la base de la coxa de algunos pereiópodos de Aegla durante la ovoposición de las hembras. El ciclo de vida descrito es similar a la gran parte de organismos que posee origen marino, por ejemplo anélidos, moluscos y crustáceos. Estos organismos han requerido adaptarse a los sistemas limnicos modifican su ciclo de vida, presentando un desarrollo con ausencia de larva planctónica lo cual asegura una mayor supervivencia en estos ambientes.

Palabras clave: Annelida, poliquetos dulceacuícolas, epibionte, Aegla laevis, Chile.

\section{INTRODUCTION}

Annelid polychaetes are mostly associated with marine environments; only 168 species belonging to 24 families have been described from freshwater systems (Glasby \&
Timm 2008). Among these freshwater polychaetes, the Histriobdellidae Family (Eunicida) is characterized by a secondarily simplified form as small-sized epibionts.

This family includes three genera; Histriobdella van 
Beneden, 1958 and Stratiodrilus Haswell, 1900, both epibionts of the branchial chambers or the ovigerous masses of marine and freshwater crustaceans (Glasby \& Timm 2008), and Dayus Steiner \& Amaral, 1999, collected in the pleopods of a marine isopod in South Africa. Species of the genus Histriobdella have been described inhabiting marine decapods of the north Atlantic and species of the genus Stratiodrilus in freshwater decapods, with a circumAntarctic distribution. Stratiodrilus has been described as an epibiont of different species from Brazil to Chile in South America and also in Australia, New Zealand and Madagascar, suggesting a Gondwanic origin of the group (Haswell 1900, 1913; Harrison 1928; Lang 1949; Vila \& Bahamonde 1985; Steiner \& Amaral 1999; Amato 2001). This clade appears to have invaded continental waters only once, in the Paleozoic or Mesozoic (Rouse \& Pleijel 2001). Reported information on this group of polychaetes is rather scarce; however, the validity of one species of the genus Histriobdella (van Beneden 1858; Shearer 1910) and 10 of the genus Stratiodrilus are recognized at present.

Descriptions of reproductive characteristics indicate that this family has mobile spermatozoids but without a flagellum; males impregnate females hypodermically in the female cavity (Lang 1949; Jamieson et al. 1985; Morrow 2004). Thus there is internal fertilization, along with large oocytes which do not grow simultaneously, indicating a continuous oviposition. Information about early embryonic development was described by Haswell (1913) for $S$. novaehollandiae Haswell, 1913 no information is available about complete larval development, hatching or adult behavior.

Two species have been recorded for Chile, Stratiodrilus aeglaphilus Vila \& Bahamonde, 1985, which inhabits the freshwater crab Aegla laevis Latreille, 1818, and S. pugnaxi Vila \& Bahamonde 1985, which is found in the branchial chambers of the Caridean Parastacus pugnax (Poeppig 1835). Their distribution area coincides with the distribution of the Aeglidae and Parastacidae in Chile, which inhabit freshwater systems from $30^{\circ} \mathrm{S}$ to $43^{\circ} \mathrm{S}$ latitude (Vila \& Bahamonde 1985; Moyano et al. 1993). In order to describe for the first time the complete life cycle of S. aeglaphilus we made counts of adults, eggs and juveniles, determining the locations and sizes of all individuals found in individuals of the freshwater crab A. laevis. The data collected allowed us to understand the adaptations of the epibionts to the fluvial crustaceans, suggesting interesting challenges related to evolutionary and dispersion aspects of these organisms.

\section{MATERIALS AND METHODS}

Samples of $S$. aeglaphilus were obtained from the Maipo River, in the Talagante area $\left(33^{\circ} 45^{\prime} \mathrm{S} ; 70^{\circ} 45^{\prime} \mathrm{W}\right)$ of central
Chile. This zone is located within the Mediterranean subhumid region of Chile (Niemeyer \& Cereceda 1984). Using hand nets, a total of 67 individuals of $A$. laevis were examined alive and anesthetized in seasonal samples before being fixed in 10\% buffered formaldehyde.

\section{HABITAT DESCRIPTION}

In order to determine the life habits of $S$. aeglaphilus, the number and locations of egg masses, juveniles and adults of $S$. aeglaphilus were counted for each individual of $A$. laevis.

\section{AnALYSIS OF ADULTS}

For the study of internal structure, individuals were fixed in both Bouin medium and in 10\% formaldehyde, stained with borate carmine and then mounted in Canada balsam. Adults were sexed based on the presence of the chitinous penis (Fig. 1). To determine possible size differences between males and females the total length of at least 100 individuals of each sex was measured. Following the Box-Cox analysis (Box \& Cox 1964), lengths were transformed to $\log (\mathrm{x})$ and the statistical difference was tested with a one-way ANOVA using the $\mathrm{R}$ software (R Core Team 2013). To examine if there is a relationship between the size of the A. laevis host and the number of females and males of $S$. aeglaphilus, a Pearson correlation analysis was performed using the $\mathrm{R}$ software. The normality of the data was obtained by a square root transformation after performing a Box-Cox analysis.

\section{ANALYSIS OF EGGS AND JUVENILES}

The degree of development of eggs and juveniles was determined using a Wild stereoscopic dissecting microscope; they were counted and total length was measured with an ocular micrometer. To examine if there is a relationship between the number of eggs of $S$. aeglaphilus and the cephalotorax of the crab A. laevis, a Pearson correlation analysis was performed using the $\mathrm{R}$ program. The normality of the data was obtained by a square root transformation after performing a Box-Cox analysis.

\section{RESULTS}

Of the 67 specimens of $A$. laevis collected, 23 were females, 43 were males and the sex of one individual could not be determined due to its small size. We found individuals of $S$. aeglaphilus in 64 of the 67 crabs; only three small A. laevis did not have the polychaete. All developmental stages were observed in each of the 64 individuals of $A$. laevis.

\section{Adults}

Males and females of $S$. aeglaphilus could be distinguished by the presence of a chitinous penis and a pair of gonopodia in the fourth body segment in males, and by the presence of large eggs and oocytes in females (Fig. 1). These 
characteristics or features were identifiable in individuals larger than about $370 \mu \mathrm{m}$. We also found sexual size dimorphism; males had a mean length of $781 \mu \mathrm{m}(\mathrm{SD}=$ 106), which was significantly higher (ANOVA; $\mathrm{F}_{1,211}=$ 36.82; $\mathrm{P}<0.01$; Fig. 2) than the mean length of females $(670 \mu \mathrm{m} ; \mathrm{SD}=105)$. We also found a significant positive correlation between the number of males and females and the size of $A$. laevis (Fig. 3).

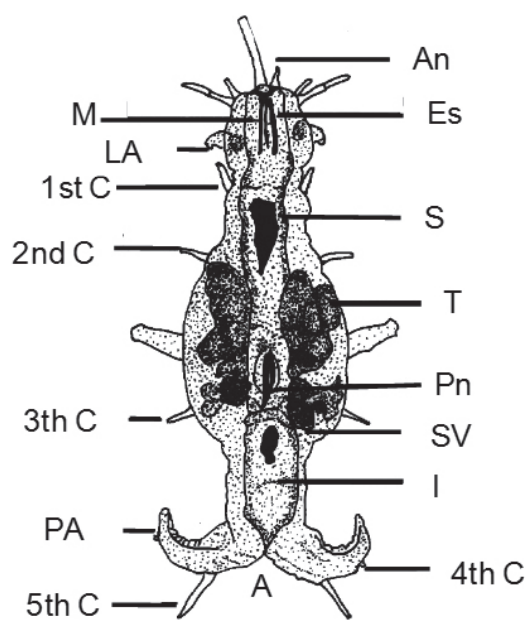

Due to its transparency, the internal structure of $S$. aeglaphilus was clearly observed under a microscope, including the membranous tube, the chitinous mandible and the oocytes; these last varied between one and ten per female, the most frequent numbers being six and seven. In the transparent digestive tubes of $S$. aeglaphilus we found the presence of epystilid protists and siliceous remains of diatom microalgae. These are apparently sucked in and fragmented by the chitinous mandibulae (Fig. 1).

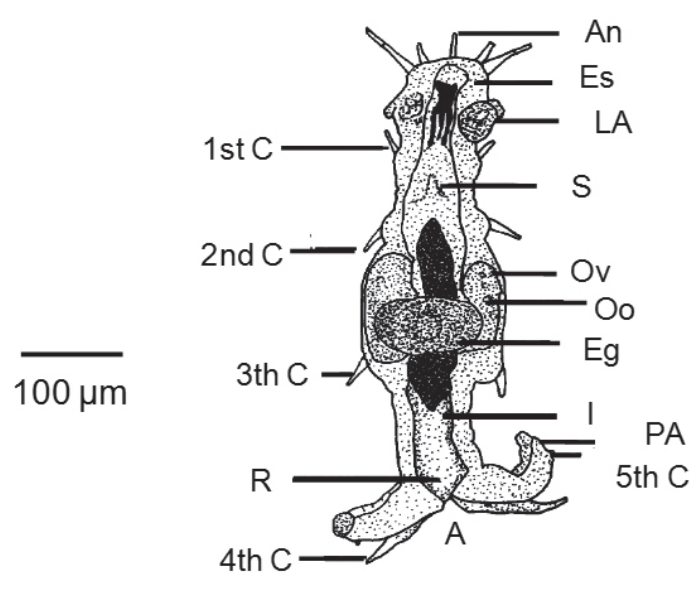

Figure 1. Male (left) and female (right) specimens. $1^{\text {st }}$ to $5^{\text {th }}$ Lateral Cirri; A= Anus; An = antennae; Eg = egg; Es = esophagus; I = intestine; $\mathrm{LA}=$ anterior parapodia; $\mathrm{M}=$ mandibule; $\mathrm{Oo}=$ oocytes; $\mathrm{Ov}=$ ovary; $\mathrm{PA}=$ Posterior parapodia; $\mathrm{Pn}=$ penis; $\mathrm{R}=$ rectum; $\mathrm{S}=$ stomach; $\mathrm{SV}$ $=$ seminal vesicle; $\mathrm{T}=$ testis; $\mathrm{Te}=$ tentacles. Scale represents $100 \mu \mathrm{m}$.

Figura 1. Especímenes macho (izquierda) y hembra (derecha). Primer $\left(1^{\text {st }} \mathrm{C}\right)$ al quinto $(5$ th $\mathrm{C})$ cirro lateral; $\mathrm{A}=\mathrm{ano} ; \mathrm{An}=\mathrm{antena} ; \mathrm{Eg}=$ huevos; Es = esófago; $\mathrm{I}=$ intestino; $\mathrm{LA}=$ parapodio anterior; $\mathrm{M}=$ mandíbula; Oo = ovocitos; $\mathrm{Ov}=$ ovario; $\mathrm{PA}=$ parapodio posterior; $\mathrm{Pn}=$ Pene; $\mathrm{R}=$ Recto, $\mathrm{S}=$ estómago; $\mathrm{SV}=$ vesícula semimal; $\mathrm{T}=$ Testículos; Te = Tentáculos. La escala representa $100 \mu \mathrm{m}$.

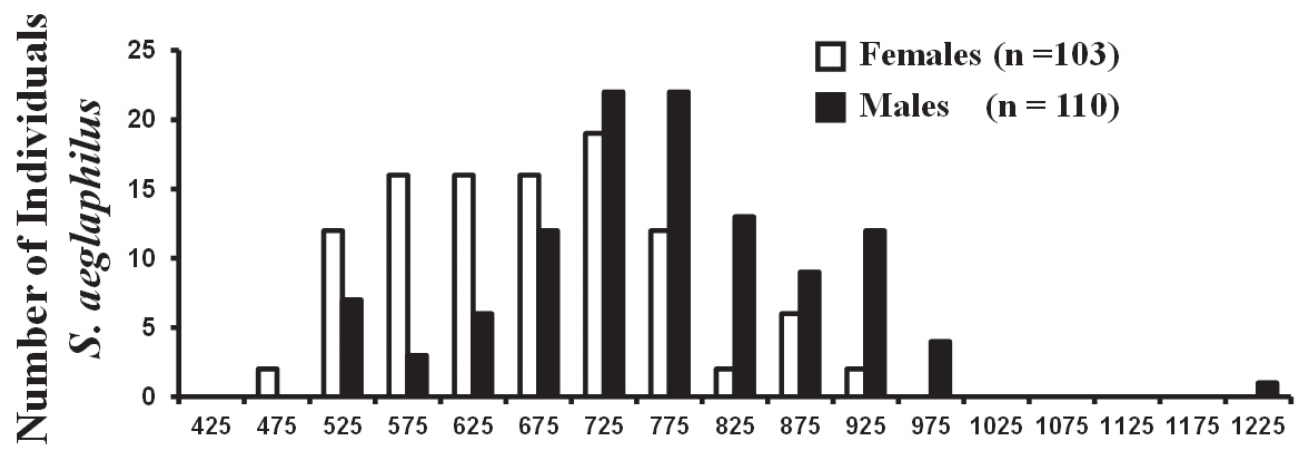

Adult Size ( $\mu \mathrm{m})$

FigURE 2. Size distribution of females $(n=103)$ and males $(n=110)$ for entire study.

Figura 2. Distribución de tamaños de hembras $(\mathrm{n}=103)$ y machos $(\mathrm{n}=110)$ utilizados en este estudio. 


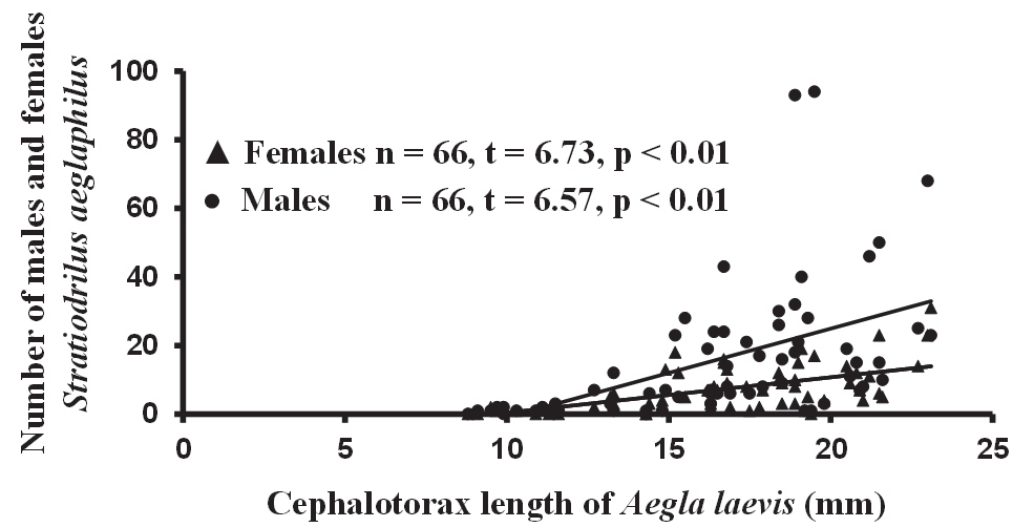

FIGURE 3. Correlation between cephalotorax length of the crab A. laevis $(\mathrm{N}=66)$ and the number of males (circles) and females (triangles) of $S$. aeglaphilus.

Figura 3. Correlación entre el largo del cefalotorax del crustáceo A. laevis $(\mathrm{N}=66)$ y el número de machos (en círculos) y hembras (triángulos) de S. aeglaphilus.

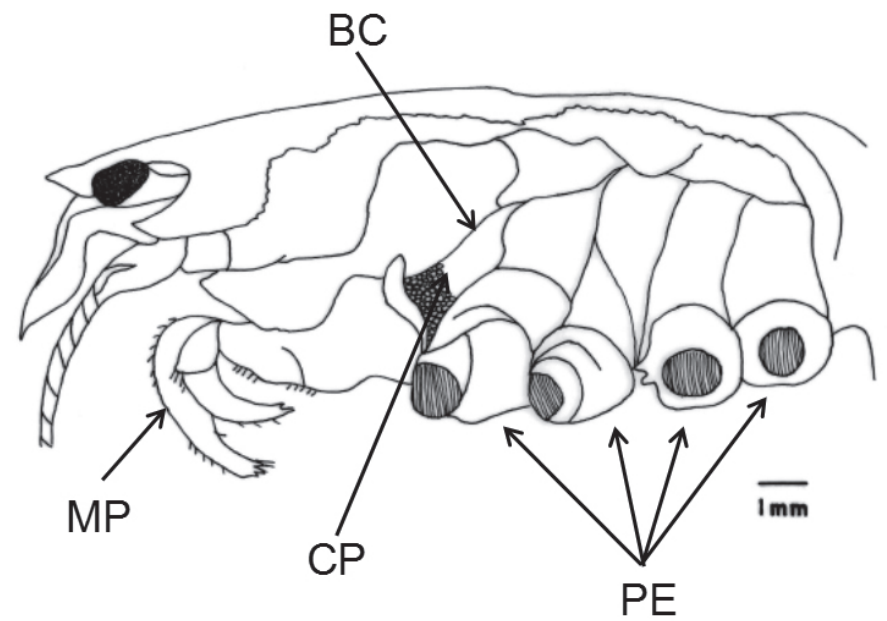

FIGURE 4. Egg location at the $A$. laevis coxal base. $\mathrm{BC}=$ branquial cavity; $\mathrm{CP}=$ coxal plate; $\mathrm{MP}=$ maxilipeds; $\mathrm{PE}=$ pereiopods.

Figura 4. Ubicación de los huevos en la base de la coxa de A. laevis. $\mathrm{BC}=$ cavidad branquial; $\mathrm{CP}=$ coxa; $\mathrm{MP}=$ maxilípedo; $\mathrm{PE}=$ pereiópodo.

EGGS AND EARLY DEVELOPMENT

In each individual of $A$. laevis we observed the eggs of $S$. aeglaphilus at different developmental stages deposited and attached in only one place, demonstrating that females migrate asynchronically to the same point for oviposition (Fig. 4). All females oviposited the fertilized eggs in the same place of the branchial cavity of A. laevis, cemented on one side to the bases of the maxillipeds or in the coxae of the pereiopods. The egg diameter varied from 99 to $213 \mu \mathrm{m}$ with a mean of $162 \mu \mathrm{m}(\mathrm{SD}=11.9$; Fig. 5). Eggs are ovate in shape with a resistant membrane; they retained their form even after being fixed and preserved in 10\% formaldehyde. The total number of eggs observed in the coxal area of a crab varied from 2 to 137 , and was positively correlated with the size of the A. laevis cephalothorax $(\mathrm{t}=3.29$; $\mathrm{p}<$ 0.01; Fig. 6).
The embryo becomes transparent as it develops; the formation of the chitinous mandible may also be observed. Figure 7 details the stages of embryo development up to hatching. Juveniles hatch with a completely structured digestive tube, they were observed feeding actively immediately after eclosion. At first juveniles are transparent, they have not yet developed gonads; they remain in the pleurobranchias where they move by fixing their posterior podia, similar to adults. Average total length at hatching was $345 \mu \mathrm{m}$. Figure $7 \mathrm{~d}$ illustrates the hatching of a juvenile individual of $S$. aeglaphilus. As juveniles grow they finish the development of the cephalic and lateral tentacles, begin to develop testicles, ovaries and a small, transparent penis which slowly chitinizes together with the appearance of ovaries and oocytes in females. 


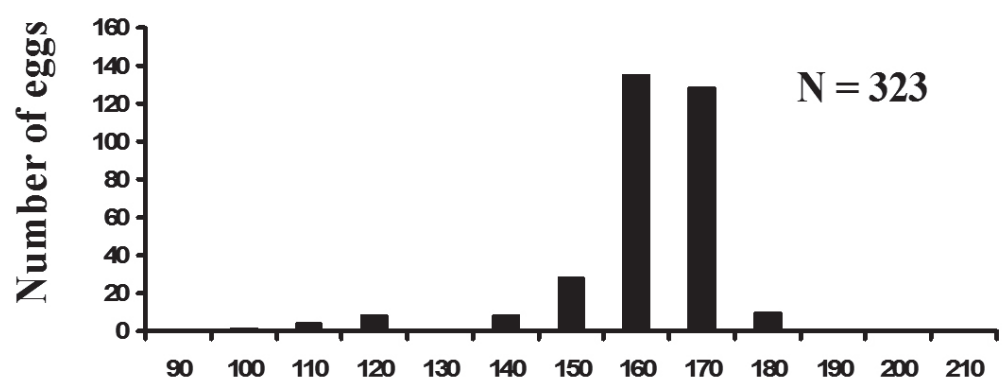

Egg Size ( $\mu \mathrm{m})$

FIGURE 5. Egg size distribution for the complete collection during the study period.

FIGURA 5. Distribución del tamaño de huevos colectados durante todo el periodo de estudio.

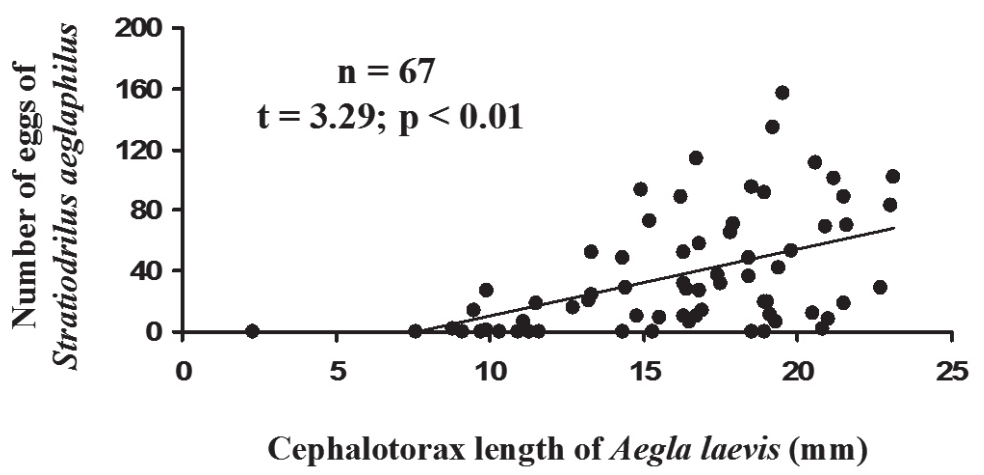

FiguRE 6. Relationship between egg number and A. laevis cephalotorax length.

Figura 6. Relación entre el número de huevos de S. aeglaphilus y el largo del cefalotórax del crustáceo A. laevis.
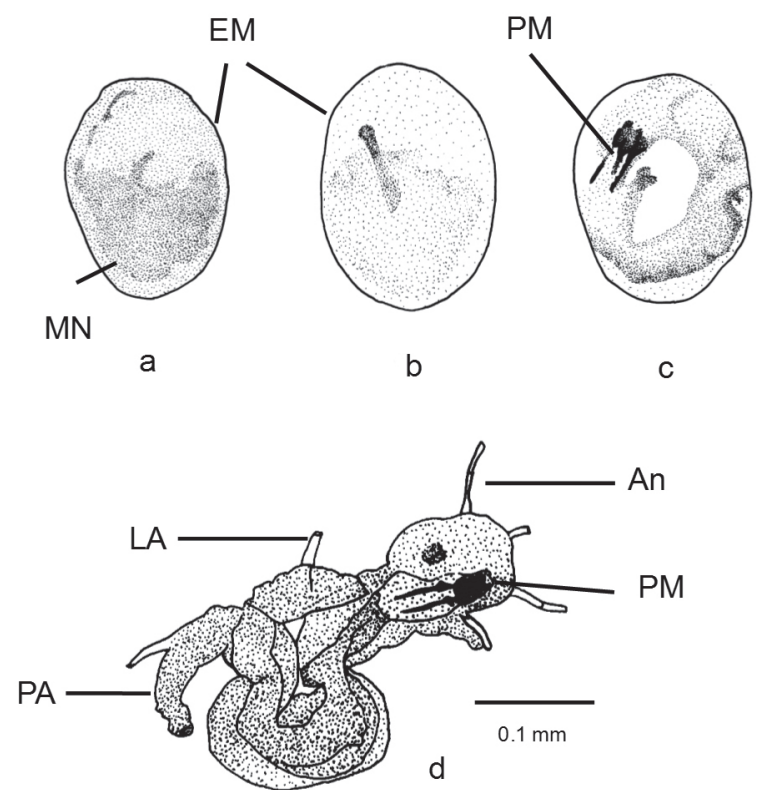

FIGURE 7. a, b, c: Development stages; d: juvenile hathing. An = antennae; $\mathrm{EM}=$ egg membrane; $\mathrm{NM}=$ nucleous membrane; $\mathrm{PA}=$ posterior parapodia; $\mathrm{PM}=$ protomandible. Scale represents $0.1 \mathrm{~mm}$.

Figura 7. a, b, c: Estados del desarrollo; d: eclosión de juveniles. An = antena; $\mathrm{EM}=$ membrane del huevo; $\mathrm{NM}=$ pared del núcleo; PA= parapodio posterior; $\mathrm{PM}=$ protomandíbula. $\mathrm{La}$ escala representa $0.1 \mathrm{~mm}$. 


\section{DISCUSSION}

S. aeglaphilus shows natural history with common characteristics with other species of commensal Histriobdellidae of marine and freshwater crabs (e.g. Shearer 1910; Haswell 1916; Simon 1968). This species is a typical epibiont in which juveniles use the branchiae of the freshwater crab A. laevis as substrate and adults move freely around the caparace. Shearer (1910) and Simon (1968) reported a similar life cycle for $H$. homari, an epibiont of the lobster Homarus americanus Van Beneden; they also reported its migration from the branchial chamber of one lobster to another. In Chile, A. laevis has been cited as having gregarious behavior during reproduction in shallow water (Bahamonde \& Lopez 1961), a suitable period for the migration of $S$. aeglaphilus among individuals of A. laevis. The stomach contents observed in $S$. aeglaphilus, was composed principally of epystilid protists and siliceous remains of diatoms which indicate that it feeds on the most abundant microorganisms found on the carapace of Aegla (Bahamonde \& López 1961, 1963). Something similar occurs in H. homari, which feeds on the microflora of the branchial chamber of the commercial lobster Homarus americanus (Jennings \& Gelder 1976).

During oviposition, eggs were observed attached and cemented to the crab pereiopod coxae. Haswell (1916) described a similar pattern of egg fixation for $H$. homari. The presence of eggs in a single place in areas with greater water circulation may indicate that eggs require high oxygen content. Although we do not have direct experimental evidence for this requirement in this species, its vital effect on the embryonic and larval development of benthonic invertebrates is well known (e.g. Booth 1995; Strathmann \& Strathmann 1995). It is expected that the region of A. laevis with greatest water circulation would be the branchial cavity, at the base of the pereiopods. Demographic responses in experimental studies with eggs, juveniles and adults of $S$. aeglaphilus demonstrated that juveniles are the most sensitive stage in the life cycle of this species (Pardo et al. 2009), which agrees with the highly oxygenated site of oviposition.

Movement of females of $S$. aeglaphilus to oviposit in a common place is a very interesting behavior. This type of migration was not random; we observed that the females oviposited their eggs asynchronically in a very specific place in the Aegla coxae of the pereiopods in the branchial cavity. Although we do not have a good understanding of the phylogeny of the group in relation to other polychaetes, since the family Histriobdellidae is usually excluded from studies (e.g. Zrzavý et al. 2009), this migratory behavior may be a common behavior in the Eunicida. The case of the free-living Palola viridis Gray in Stair, 1847, which migrates to a common reproductive area at a specific time on one day of the year, is well known. We do not wish to speculate on this hypothesis, but we feel that the idea is interesting enough to warrant phylogenetic studies which could accept or reject the suggestion.

Interestingly, the absence of a free swimming larva is commonly observed in diverse taxa inhabiting freshwater systems with a marine origin, for example crustaceans (Bahamonde \& Lopez 1961; Cumberlidge 1999), gastropods (Callow 1978) and annelids (Glasby \& Timm 2008). Barnes et al. (1993) pointed out that the presence of a large number of species with direct development in freshwater environments could be explained by the pressure which freshwater entails. These organisms have the typical adaptation to freshwater systems such as being viviparous and having eggs with impermeable membranes, internal fecundation and high maternal investment with low egg number.

The presence of oocytes in females throughout the year and of embryos with different degrees of development suggests that $S$. aeglaphilus is an iteroparous species. This may be a key element to the survival of this species, given the constant molting of the shell by the host species, along with the evolution of direct development in S. aeglaphilus. Direct development may also be influenced by the life cycle of the crustacean, which is migratory in rivers that have a very variable and unstable flow. Our results also demonstrate that $S$. aeglaphilus completes its life cycle on individuals of $A$. laevis, generating a population in each individual of the aeglid crab. Additional information about levels of relatedness and parentage would be necessary to confirm this idea.

The life cycle of $S$. aeglaphilus is unique among polychaetes since it completes its life cycle in each individual Aegla. This behaviour raises interesting phylogenetic and ecological questions, such as how $S$. aeglaphilus gets established in the juvenile crabs and the permanence of each stage of development when considering the process of molting of the crabs. Finally, it is interesting to know about the survival of A. laevis and S. aeplaphilus given the scenario of water decrease and high pollution observed in most Mediterranean sub-humid rivers of Chile.

\section{ACKNOWLEDGMENTS}

Thanks to L. Uribe for drawing the specimens, D. Véliz for figures and L Eaton for comments. Partially supported by Fondecyt 1100341, ICM P05- 002 and PFB-23. 


\section{BIBLIOGRAPHY}

Amato, J.F.R. 2001. A new species of Stratiodrilus (Polychaeta : Histriobdellidae) from freshwater crayfishes of southern Brazil. Iheringia, Série Zoologia 90: 37-44.

Bahamonde, N. \& LóPez, M.T. 1961. Estudios biológicos en la población de Aegla laevis laevis (Latreille) en el Monte. Investigaciones Zoológicas Chilenas 7: 19-58.

Bahamonde, N. \& López M.T. 1963. Decápodos de las aguas continentales de Chile. Boletin del Museo de Historia Natural Chile 10: 123-149.

Barnes, R.S.K., Calow, P. \& Olive, P.J.W. 1993. The Invertebrates. A New Synthesis. $2^{\text {nd }}$ Edition. 488 pp. Blackwell Scientific Publications. London.

Beneden, P.J.V. (1858). «Histoire naturelle d'un animal nouveau designe sous le nom d' Histriobdella «. Bulletin de l'Académie Royale Belgique, Bruxelles 5: 270-302.

Bоотн, D. 1995. Oxygen availability and embryonic development in sand snail embryo masses. Journal of Experimental Biology 198: 241-247.

Box, G.E.P. \& Cox D.R. 1964. An analysis of transformations. Journal of the Royal Statistics Society, series B 26: 211252.

Calow, P. 1978. The evolution of life-cycle strategies in freshwater gastropods. Malacologia 17: 351-364.

Cumberlidge, N. 1999. The freshwater crabs of West Africa: Family Potamonautidae. IRD Editions. 382 p.

Glasby, C.J. \& Tiмm, T. 2008. Global diversity of polychaetes (Polychaeta : Annelida) in freshwater. Hydrobiologia 595: 107-115.

HARrison, L. 1928. On the genus Stratiodrilus (Archiannelida : Histriobdellidae), with description of a new species from Madagascar. Records of the Australian Museum 16: 116121.

Haswell, W.A. 1900. On a new Histriobdellidae. Quarterly Journal of Microscopical Science 43: 299-335.

Haswell, W.A. 1913. Notes on the Histriobdellidae. Quarterly Journal of Microscopical Science 59: 197-359.

Haswell, W.A. 1916. On the Embryology of Stratiodrilus (Histriobdellidae). Quarterly Journal of Microscopical Science 61: 301-312.

Jamieson, B.G.M, Afzelius, B.A. \& Franzen, A. 1985. Untraestructure of acentriolar, aflagellate spermatozoa and the eggs of Histriobdella homari and Stratiodrilus novaholladiae (Histriobdellidae : Polychaeta). Journal of Submicroscopic Research 17: 363-380.
Jennings, J.B. \& Gelder S.R. 1976. Observations on the feeding mechanism, diet and digestive physiology of Histriobdella homari van Beneden 1858: an aberrant polychaete symbiotic with North American and European lobsters. Biological Bulletin 151: 489-517.

LANG, K. 1949. Morphology of Stratiodrilus platensis. Arkiv fur Zoologi 42: 43-47.

Morrow, E.H. 2004. How the sperm lost its tail: the evolution of aflagellate sperm. Biological Reviews 79: 795-814.

Moyano, H., Carrasco, F. \& Gacitúa, S. 1993. Sobre las especies chilenas de Stratiodrilus Haswell, 1900 (Polychaeta : Histriobdellidae). Boletín de la Sociedad de Biología de Concepción, Chile 64: 147-157.

Niemeyer, H. \& Cereceda P. 1984. Hidrografía. Geografía de Chile. Tomo VIII. Instituto Geográfico Militar, Chile 320 pp.

Pardo, R., Vila, I. \& Bustamante, R. 2008. Demographic response of Stratiodrilus aeglaphilus (Anelida : Histrobdellidae) to organic enrichment: experimental assessment. Hidrobiología 598: 11-16.

R CoRe TEAm. 2013. R: A language and environment for statistical computing. R Foundation for Statistical Computing, Vienna, Austria. URL: http://www.R-project.org/.

Rouse, G.W. \& PleiJel, F. 2001. Polychaetes. Oxford University Press Inc, New York, USA.

SHEARER, C. 1910. On the anatomy of Histriobdella homari. Quarterly Journal of Microscopical Science 55: 287-359.

Simon, J. 1968. Incidence and behavior of Histriodella homari (Annelida : Polychaeta), a commensal of the American Lobster. BioScience 18: 35-36.

Steiner, T.M. \& AMARAL, A.C.Z. 1999. The family Histriobdellidae (Annelida, Polychaeta) including descriptions of two new species from Brazil and a new genus. Contribution to Zoology 68: 95-108.

Strathmann, R. \& Strathmann, M. 1995. Oxygen supply and limits on aggregation of embryos. Journal of the Marine Biological Association of United Kingdom 75: 413-428.

Vila, I. \& Bahamonde, N. 1985. Two new species of Stratiodrilus, S. aeglaphilus and S. pugnaxi (Annelida : Histrobdellidae) from Chile. Proceedings of the Biological Society of Washington 98: 347-350.

ZrzavÝ, J., Ř́íha, P., PiÁlek, L. \& JanouŠKovec, J. 2009. Phylogeny of Annelida (Lophotrochozoa): total-evidence analysis of morphology and six genes. BMC Evolutionary Biology 9: 189.

Recibido: 15.04 .13

Aceptado: 03.12.14 